\title{
Delineating the Urban: The Global City and the Logics of Dissolution
}

Jarrad Keyes

\section{(2) OpenEdition}

\section{Journals}

\section{Electronic version}

URL: http://journals.openedition.org/transtexts/145

DOI: $10.4000 /$ transtexts. 145

ISSN: 2105-2549

\section{Publisher}

Gregory B. Lee

\section{Printed version}

Date of publication: 1 September 2007

Number of pages: 98-118

ISSN: 1771-2084

\section{Electronic reference}

Jarrad Keyes, «Delineating the Urban: The Global City and the Logics of Dissolution », Transtext(e)s Transcultures 跨文本跨文化 [Online], 3 | 2007, Online since 15 October 2009, connection on 24 April 2019. URL : http://journals.openedition.org/transtexts/145 ; DOI : 10.4000/transtexts. 145 


\title{
Delineating the Urban: The Global City and the Logics of Dissolution
}

\author{
JARRAD KEYES
}

This paper analyzes the recent critical interest in the global city, and assesses the significance of what it calls the city-urban transaction. This latter term refers to a tendency amongst recent approaches to offset waning city definition the rise of the urban, and lament the former in the name of the latter. The point of departure for this reading concerns the relationship between models of development and the often disparaging figuration of the urban. It rejects the technological determinism of William Mitchell and Pierre Lévy, and the idealism of Manuel Castells, to suggest that, whilst the urban engenders the dissolution of orthodox accounts of the city, it does not entail a correlative sense of ontological degradation. In rejecting the negative, amorphous connotations frequently thrust upon the urban, the paper concludes with a reading of John King's fiction so as to provide a tentative sketch of the logics of dissolution as seen in a positive light.

«Each city receives its form from the desert it opposes» ${ }^{1}$

«Compact cities are at the other end of the pole from urban sprawl $»^{2}$

«[I]n great leprous stains, the suburbs spread out from the outlying districts, polluting the countryside and reducing the outskirts of the town to a miserable and shifting shabbiness» ${ }^{3}$

${ }^{1}$ Italo Calvino, Invisible Cities, Harcourt Brace Jovanovich Inc, London: Pan Books, 1979, p.18. ${ }^{2}$ Richard Rogers and Anne Power, Cities For A Small Country, London: Faber \& Faber, 2000, p.281. 


\section{Introduction}

In the face of complex and seemingly relentless changes - commonly deemed «a world of ubiquitous computation» - it is undoubtedly tempting to attempt to reverse the passage of time, and find moment(s) replete with lost certainties. ${ }^{4}$ With respect to the city, such nostalgia is a pervasive aspect of present inquiry; if there is some semblance of consensus regarding its contemporary «plight», it is that the city has been, at one point or another, a stable signifier. A point, moreover, from which the present marks a critical juncture. ${ }^{5}$ Frequently, this challenge is posited as the result of increasingly globalized phenomena, in the form of technology. For William Mitchell, «the story of recent urban growth» is one of «network-induced sprawl», such that «the very idea of a city is challenged and must be reconceived», whilst for Manuel Castells it is not so much evolution as degeneration, since «the very existence of cities as communication artefacts ... is called into question, in spite of the fact that we live in a predominantly urban world». ${ }^{6}$ It is in this context that the opposition between the "global city» and the «urban» emerges. This restrictive economy, wherein the epithet «urban» appears as the debased obverse of the city is considered symptomatic of contemporary readings. Henceforth referred to as the city-urban transaction, this incumbent problematic represents, so this paper contends, the transference of an outdated series of epistemological co-ordinates onto incompatible ontological matrices. Critiquing the various formations of identity and disidentity with which readings of the global city are preoccupied, this paper analyzes several of its readings, and their respective models of development, in order to contest the increasingly distended usage of global epithet. Addressing the ramifications of the city's perceived disintegration, it concludes with a reading of John King's fiction to provide a tentative sketch of the logics of dissolution as seen in a positive light.

\section{Global \& Urban Contexts}

According to Stephen Graham, the «critical question» presently concerning the city involves determining «the relationship between digital technologies and urban

${ }^{3}$ Le Corbusier, Concerning Town Planning, trans. Clive Entwistle, London: The Architectural Press, 1947, p.56.

${ }^{4}$ William J. Mitchell, City of Bits: Space, Place, \& the Infobahn, Cambridge, MA.: MIT Press, 1996, p.107. ${ }^{5}$ For example, see Saskia Sassen, The Global City: New York, London, Tokyo, New Jersey: Princeton University Press, 1991.

${ }^{6}$ William J. Mitchell, Me++: The Cyborg Self and the Networked City, Cambridge, Mass.: MIT Press, 2003, p.10; Manuel Castells, «Space of Flows, Space of Places: Materials for a Theory of Urbanism in the Information Age», in Stephen Graham, ed., The Cybercities Reader, London: Routledge, 2004, pp.83-93. 
life».7 By way of response, Castells divides the «network society» between the competing imperatives of the "space of flows» (of technological networks) and the «space of places» (arranged around locality) that result in the «opposition between the global and the local».8 Polarized between the spaces of «flows» and «places», the city (equated with the «local») is subject to the «global» effects of digital technologies. Hence, a structural tension involving the conflict between «personality and culture» precipitates «the crisis of the city as a socio-spatial system of cultural communication». ${ }^{9}$ Understood as an antagonistic force, this «global» sum of technological networks offsets the local-level «crisis» with the «concept of the global city» as «a spatial form rather than a title of distinction», and laments the former in the name of the latter. As a «spatial form», the global city infers a kind of formless structure whose size and lack of definition countervails the city. In short, technology, in the aggregated forms of «flows», obtrudes the "personality» of the city as a «system of cultural communication». It is important to note distinct uses of the term: the global city refers to a distended physical morphology, whereas the «system of cultural communication» draws upon a political definition. In sum, the distinction involves qualitative and quantitative discriminations. Doubly formed, the city is both a metonym of polity and a component of representation.

To return to the critical question concerning technology, Castells critique works on two levels. Firstly, there is a familiar (humanist) response, whereby technology usually in an unqualified, general sense - infringes upon the sanctity of (human) meaning. ${ }^{10}$ Thus, the «spaces of flows» impact negatively upon the qualitative definition of the city as a «system of cultural communication». This infraction leads to the second level of critique, the emergence of the urban. Understanding the global city as an oxymoron, it juxtaposes the receding essence of cities with an «urban world» that, as part of the "great urban paradox», constitutes «the crisis of the city». ${ }^{11} \mathrm{~A}$ «crisis» inextricably linked to its rationalist origins as a metonym of

\footnotetext{
7Stephen Graham, ed., The Cybercities Reader, p.3. Graham 's use of «urban life» in place of the «city», is not pejorative.

${ }^{8}$ Manuel Castells, «Space of Flows, Space of Places: Materials for a Theory of Urbanism in the Information Age», p.85.

${ }^{9}$ Manuel Castells, p.83.

${ }^{10}$ One such instance is «the accusation is that the uncontrolled growth of technology destroys vital sources of our humanity. It creates a culture without moral foundation. It undermines certain mental processes and social relations that make human life worth living». See Neil Postman, Technopoly: The Surrender of Culture to Technology, New York: Vintage Books, 1993, p.xii. ${ }^{11}$ Manuel Castells, «Space of Flows, Space of Places: Materials for a Theory of Urbanism in the Information Age», p.86, p.89 and p.90.
} 
governmental rationality. ${ }^{12}$ Its breakdown attests to a particular sense of political failure, codified comparatively in terms of physical deterioration. On this account, challenges to hegemony of rational (political) order are negotiated as a (physical) «urban crisis ... characterized by dissolution, fragmentation, and privatization of cities». ${ }^{13}$ Therefore, the logics of dissolution affecting the city can only be structured negatively in terms of a perceived breakdown in order, socially and physically: 'Far from being orderly, attractive and well designed', Richard Rogers notes, «our urban landscape is full of unplanned ruptures». The result: «Cities have lost the connected, dense style that characterized them in the past», testaments to the fact that "[a]s social cohesion and informal controls weakens, so our ability to contain disorder and violence declines». ${ }^{14}$ These are the assumptions out of which the "global city», as a «spatial form», emerge: the loss of rational order can only be represented as social and physical «crisis». Yet that which specifically defines the city, in particular its sense of order, present and past, remains conspicuously absent. For the present to represent «crisis» requires a set of foundational qualities to be, presently, under threat. Yet these assumed qualities have, contrary to the specific latitude of the «network society», long been threatened.

«We are slowly losing the humanist conception of the very meaning of the word "city". Paradoxically we live in a world marked by rampant urbanization - but one that lacks real cities. As the once clearly demarcated cities inherited from the past are devoured by the expanding metropolis, the city begins to lose its definition and specificity, as well as its function as an authentic arena for community and solidarity.» ${ }^{15}$

This «paradox» besets the city-urban transaction. As metonym, the «humanist conception» of «real cities» retrenches relative to the rise of «rampant urbanisation». The homogenizing force of the «expanding metropolis» devours the «once clearly demarcated cities» of the past, contaminating the inferred originary physical characteristics of «definition and specificity» and eradicating the social functions of «community and solidarity». Prefiguring Castells, Bookchin represents the perceived diminution of qualitative social relations through the quantitative spatial

\footnotetext{
${ }^{12}$ Originating in the early seventeenth century, this understanding posits the city as «'the model for the governmental rationality that was to apply to the whole of the territory», such that it became «the matrix for the relations that apply to a whole state». Michel Foucault, «Space, Knowledge, and Power» in James Faubion, ed., Power: Essential Works of Foucault 1954-1984, Vol. 3, trans. Robert Hurley et al, London: Penguin, 2002, p.351.

${ }^{13}$ Manuel Castells, «Space of Flows, Space of Places: Materials for a Theory of Urbanism in the Information Age», p.91. For a similarly vague progenitor, see Le Corbusier, Concerning Town Planning. ${ }^{14}$ Richard Rogers and Anne Power, Cities For A Small Country, London: Faber \& Faber, 2000, p.43 and p.57.

${ }^{15}$ Murray Bookchin, The Limits of the City, New York: Harper \& Row, 1974, p.vii.
} 
matrix of morphology: the principle of diminishing community registers as the rise of the compromised urban form. This figuration assumes "community» to be indivisible from a particular physical form (the city), and vice-versa. Trapped by this stultified logic, the deployment of the city indeterminately wavers between simultaneous determinations as a rationalist metonym and a positivist concept. As if to confirm this originary indeterminacy, it remains unclear as to which city, moreover which «world», is «marked by rampant urbanization». In the absence of considered response, beyond the vague inferences of foundational autonomy, there is little that specifically defines the city, save its present absence (or self-evident role as «authentic arena»). That these developments take place without explanation suggests the symbolic and ideological system of its conceptual pre-history place the city's origins (as rational and contiguous) beyond the purview of critical inquiry. The effects of this are as follows: polarized between states of past integrity and present dissolution, and leaving no interstitial «space» (epistemologically or otherwise), this discursive routine pejoratively utilizes the urban as index of a listless present, sine qua non the "global city». Such is the power of the «urban" conviction that the burden of proof lies not with the diagnostician, for which the rigour of self-evidence removes such inconveniences. Instead, it attests, moreover demonstrates, the present (as) «condition». Hence, the typology of «nameless urban constellations» is a euphemism whose spatial inferences parallel the historical connotations of the «urban crisis». ${ }^{16}$ Synchronically, the «urban world» signifies an entropic drift of characterless space(s) - space without place, lacking «symbolic meaning» - whilst diachronically the «urban crisis» symbolises the perceived disintegration of the city. Again, prescient questions of the origins and legitimacy of conferred identity are ignored. Such ellipses define the city-urban transaction, for the structural bases of legitimacy are seldom questioned. Whilst tentatively recognizing some form of hermeneutic watershed, the «global city» fails to embrace the full significance of change. Fraught with anxiety, the challenge to the assumed foundational characteristics of the city - as rational, autonomous, and coherent can only be registered in terms of a fundamental breach, for which the undermining of a particular form is codified as a spatial formlessness. The syntagmatic relay between «urban» and «metropolitan» symbolises an historical and spatial rupture, an ontological contamination for which the "process of reconstruction", with its emphases on «restoring functional communication» and «reinstating the city» by focusing «on the preservation, restoration and construction of public space», is an

${ }^{16}$ Manuel Castells, «Space of Flows, Space of Places: Materials for a Theory of Urbanism in the Information Age», p.86. 
ideology of the return. ${ }^{17}$ Moreover, the lack of coherence said to beset the global city is, at the selfsame time, applicable to Castells model. Where the «information age» is «marked by the growing gap between splintering networks of instrumentality and segregated places of singular meaning», so these «segregated places» cannot have a «singular meaning» since they are upheld as declining instances of the city.18 In other words, these "places» cannot be singular unless the concept of the city recognises a plurality of definitions - both physical and social - for which there can be no totalizing definition, «crisis» or otherwise. Unable to distinguish places and spaces, let alone concept and re-presentation, what remains is a paradigmatic indolence that confuses epistemological dissolution with ontological disintegration. In this, Castells is not alone.

Furthering Castell's idea of «functional » Mitchell suggests that recent technological developments «change the fundamental mechanics of reference», such that «the very idea of a city needs overhauling». ${ }^{19}$ In response to Graham's «critical» question, «the worldwide computer network» gives rise to «the electronic agora», an entity that «subverts, displaces, and radically redefines our notions of gathering place, community, and urban life». ${ }^{20}$ Unlike Castells, Mitchell suggests such technological developments prompt a qualitative shift in understanding and re-presentation: the 'electronic agora' does not result in the «crisis» of the city - far from it. Rather, it provokes a paradigmatic shift, recognizing «a networked, electronically interconnected world» that involves the «the shift from a world structured by boundaries and enclosures to a world increasingly dominated, at every scale, by connections, networks, and flows». ${ }^{21}$ The urban in this instance refers to the development and dispersal of technological networks. Fundamentally modified by «digital technologies», «urban life» entails that the city must be re-envisioned. Correspondingly, the spread of the «networked city» involves a quantitative change in the city's morphology and a qualitative change in social relations. Ostensibly anti-essentialist, Mitchell's account of the city appears flexible and contingent. However, far from re-conceiving «the idea of the city», Mitchell's account remains steeped in an orthodox series of assumptions. ${ }^{22}$ For instance, as a metaphor of development, «sprawl» connotes an outgrowth beyond a normative

${ }^{17}$ Manuel Castells, pp.89-90. The interchangeable use of «metropolitan world» (90) and «urban world» $(86,89,92)$ recognizes these epithets as generic typologies, whose status is such that they do not warrant consistent application

${ }^{18}$ Manuel Castells, p.92.

${ }^{19}$ Manuel Castells, pp.85-6; William J. Mitchell, City of Bits: Space, Place, $\mathcal{E}$ the Infobahn, p.120 and p.107

${ }^{20}$ William J. Mitchell, City of Bits: Space, Place, \& the Infobahn, Cambridge, MA.: MIT Press, 1996. p.8.

${ }^{21}$ William J. Mitchell, Me++: The Cyborg Self and the Networked City, p.5.

${ }^{22}$ William J. Mitchell, Me++: The Cyborg Self and the Networked City, p.10. 
point of identity: digital technologies extend the realm of the urban beyond its previous «fringes». Yet that which constitutes these previous limits remains evasive. If 'the story of recent urban growth' details «network induced sprawl at the fringes», leading to a reappraisal of the city, it is only insofar as it was perceived as rationally delimited. ${ }^{23} \mathrm{~A}$ crucial difference between Castells and Mitchell rests on their respective interpretation of «urban sprawl» and its effect on the «idea» of city. However, the differences are not so great as first appears. Take, for example, the model of development, for which the choice of metaphor is telling. Alternately described as the «infobahn ecosystem», the «electronic agora» is a «ferociously Darwinian place that produces endless mutations». ${ }^{24}$ Yet in stark contrast to the evolutionary inferences of the Darwinian metaphor, these «large, decentralised networks that increasingly dominate our globalized world», assume a linear - and far from mutable - form, as the «Hertzian landscape». 25

«Code is weaving an ever-denser web of complex, inescapable interconnections across space and time. And this is just the beginning; the curve of technological development is snapping into the steep part ... Every point on the surface of the earth is now part of the Hertzian landscape ... [a] messy but irresistible extension of wireless coverage. $\rangle^{26}$

«Code», an analogue for digital technologies, denotes a «web» of 'inescapable interconnections' that contradict suggestions that this «landscape frames a complex geopolitics and political economy of wireless coverage».27 Assuming a teleological character, «technological development» is «just ... beginning» its «curve» of ascent - a linear trajectory encompassing «every point» of the earth's surface. Paradoxically, this nascent «development» is both «messy» - presumably in the sense of uneven patterns of development and dispersal - and constitutes a «sophisticated, well-integrated wireless infrastructure ... deployed on a global scale». ${ }^{28}$ At once emergent and developed, «messy» and «integrated», there is little consistency in Mitchell's reading, save for its unyielding technological determinism. These networks cannot be both «decentralised» and form part of the «irresistible extension» of the urban. If, for Castells, the global city results in the spread of «nameless urban constellations» and prompts the city's «crisis», for Mitchell the future is similarly indiscriminate. The city and urban, mutually exclusive terms for Castells, are for Mitchell synonymous. Far from «emerging», in a non-linear,

${ }^{23}$ William J. Mitchell, Me++: The Cyborg Self and the Networked City, p.10, italics added.

${ }^{24}$ William J. Mitchell, City of Bits: Space, Place, E the Infobahn, p.4.

${ }^{25}$ William J. Mitchell, Me++: The Cyborg Self and the Networked City, p.175, italics added.

${ }^{26}$ William J. Mitchell, Me++: The Cyborg Self and the Networked City, p.5, p.55, and p.57, italics added.

${ }^{27}$ William J. Mitchell, Me+t: The Cyborg Self and the Networked City, p.55.

${ }^{28}$ William J. Mitchell, Me++: The Cyborg Self and the Networked City, p.57. 
asymmetric sense - this «fundamentally new urban condition» is the teleological goal of development, seamlessly integrated into an undifferentiated future wherein «zones of networked interdependence ... grow ... in rapid, unbounded fashion ... [and] inexorably fuse into a single global system». ${ }^{29}$ Growth, the process of development, follows a preordained, inviolable path towards the «single global system». Aptly referred to as a "condition», in the singular sense, such totalizing gestures undercut notions of «decentralized», «messy» development. The «networked world» is so distended as to be critically redundant; its scope so totalizing, it becomes impossible to distinguish between technology as metaphysic and as embedded physical infrastructure.

A similar determinism operates philosophically, for the model informing this theory of development is not Darwinian: «[t]here is no «law» within the theory of natural selection that would enable one to claim that evolution displays any kind of teleological progressivism». ${ }^{30}$ On the contrary, it is quasi-Hegelian. ${ }^{31}$ To suggest that a diverse series of networks comprise a «single global system» belies the manifold contradictions of development, technological or otherwise. ${ }^{32}$ Far from being «unbounded», development is a political issue, as Mitchell tentatively acknowledges. ${ }^{33}$ To contend such developments constitute a single, contiguous «system» is to ignore this fact, and at some cost. Mitchell's determinism is such that, ultimately, technological development assumes the rank of an independent variable, detached from the material contradictions it develops out of. The global city as «electronic agora» is a neo-liberal ideology that elides the material aspects of inequality, a specious urbanism «dissimulating its fundamental features, meanings, and finality». ${ }^{34}$ Principal amongst these forms of dissimulation is the tendency to concentrate on the «symbolic power» of digital technologies, and so ignore the fact that «[r]ather than ushering in some global democratic utopia, the best global ICT

\footnotetext{
${ }^{29}$ William J. Mitchell, Me+t: The Cyborg Self and the Networked City, p.112 italics added; and pp.210-11 ${ }^{30}$ Keith Ansell-Pearson, Viroid Life - Perspectives on Nietzsche and the Transhuman Condition, London: Routledge, 1997, p.171.

${ }^{31}$ The «grand narrative [of technology] today», Keith Ansell-Pearson (1997: 4) notes, is often that of a «facile quasi-Hegelianism in which the rise of the machine is construed in linear and perfectionist terms»; eith Ansell-Pearson, p.4.

${ }^{32} \mathrm{On}$ the differences between concept and material development, see Bruno Latour, Aramis or the Love of Technology, Cambridge, Mass.: Harvard University Press, 1996.

${ }^{33}$ «In September 2001, there was more fibre optic cable under the streets of Manhattan than in all of Africa ... [and] the two main telephone switches in the Financial District had more lines than many European nations», William J. Mitchell, Me++: The Cyborg Self and the Networked City, p.176.

${ }^{34}$ Henri Lefebvre, The Urban Revolution, trans. Robert Bononno, Minneapolis: University of Minnesota Press, 2003, p.156. Urbanism - as an ideology of spatial representation and practice - is politically significant, since, «[b]eneath its benign exterior, humanist and technological, it masks capitalist struggle: the control of space....and so on.»
} 
[information and communications technologies] connections are in the hands of the corporate and military world». ${ }^{35}$ This specious, «incorporeal world of the Net» conceives of the urban as a vague and totalizing form, whose lack of differentiation erases the spatial contours and physical traces of «power».36

In more speculative terms, Pierre Lévy speaks the «virtual agora» as the product of «the turbulent waters of anthropological mutation». ${ }^{37}$ Assuming its telos to be an anthropomorphic extension of agency and means of revitalising community, cyberspace is posited as «mankind's emerging world», an immaterial realm in which «[w]e are no longer in historical time, with its references to writing, the city, the past». ${ }^{38}$ On Lévy's reading, the global city, synonymous with cyberspace, offsets a material world marked by «[e]pidemics of civil war» and «[t]he impossibility of founding cities». Consigned to a (material) past, the city is transposed by an avowedly idealist solution: cyberspace «will not develop within any known geographic territory, institution, or state», and yet will promote «new qualities of being and new ways of fashioning a society». ${ }^{39}$ For the purposes of this paper, the weaknesses inherent to this reading of «digital utopia» are not of primary importance. ${ }^{40}$ That said, this is not to dismiss the utility of Lévy's reading, for its use of the city-urban transaction more fully exposes the negative dynamics of the logics of dissolution.

«Circulation devours, covers, obscures, buries, and deafens the city ... pierces, tears, and dissects the countryside. The territorial distinction between the city and the country is no longer relevant and gives way to urban life ... [which] grows and metastasizes ... marked by the detritus left behind by multitudes of intersecting currents; the urban space is a city whose centre is everywhere and whose circumference nowhere.» ${ }^{41}$

The tendency to contrast a fragmented material domain with the integrity of cyberspace is a pervasive feature of digital narratives: the theme of technological unity is not considered «in isolation, but unity contrasted with multiplicity, particularly as understood pejoratively as fragmentation or disintegration. The

${ }^{35}$ Stephen Graham, ed., The Cybercities Reader, p.21.

${ }^{36}$ William J. Mitchell, City of Bits: Space, Place, \& the Infobahn, p.10.

37Pierre Lévy, Collective Intelligence: Mankind's Emerging World in Cyberspace, trans. Robert Bononno, Cambridge MA: Perseus Books, 1997, p.57.

${ }^{38}$ For a similarly humanist reading of technology, see Ollivier Dyens, Metal and Flesh. The Evolution of Man: Technology Takes Over, trans. Evan J. Bibbee \& Ollivier Dyens, Cambridge, MA: MIT Press, 2001. ${ }^{39}$ Pierre Lévy, Collective Intelligence: Mankind's Emerging World in Cyberspace, p.xxv.

${ }^{40}$ Richard Coyne, Technoromanticism: Digital Narrative, Holism, and the Romance of the Real, London: MIT Press, 1999.

41Pierre Lévy, Collective Intelligence: Mankind's Emerging World in Cyberspace, p.177. 
fragmentation is either outside the world created by technology or within it».42 Such instances of fragmentation are caused by "circulation», a euphemism for the various forms of technologies aggregated under the «spaces of flows». Whilst broadly similar to Castells reading, Lévy's point of divergence concerns its probing of the city-country binary. Superficially, the traditional binary epistemology - of nature divorced from culture, as a «territorial distinction» - is under threat. «Circulation» (a metonym for the multifarious forms of technologies that mediate modern life), insofar as it «devours» the city and «dissects» the countryside, heralds the onset of «urban life». Yet this is not seen as a positive step, for the logics of dissolution are negatively exposed through the pejorative inferences of the urban. Consistent with its dominant use within global city narratives, the urban is predominantly symbolic. Structurally polarized between a technological utopia and a fragmented urban present epitomised by «[t]he clamorous Babel of global metropolises», Lévy's reading makes extensive use of a series of traditional tropes of representation. 43

Coded as a sprawling edifice devoid of specificity, and heralding an incumbent ontology, the urban space represents one manifestation of a wider contemporary pathology, «urban life, that grows and metastasizes». To better understand the symbolic functions of the urban within the city-urban transaction, this section focuses on several metaphors of development in greater detail. Etymologically related to metastasis, «metastasize» negotiates geographical anxieties through the «symbolic realm» of biology. ${ }^{44}$ In biological terms, metastasis denotes «the transformation of chemical compounds into other compounds in the process of assimilation by an organism». ${ }^{45}$ Metaphorically, the breakdown of the city/countryside dualism equates to the assimilation of an originary, spatially bounded condition of authenticity («territorial distinction») by an amorphous state of degeneracy («urban space»). The interchangeable use of the urban epithet, diachronically shifting between «-life» and «-space», intimates a wider process of social entropy, gauged by the proximate decline of the city. Consistent with its earlier usage, the city - as symbol of polity and morphology - becomes a

${ }^{42}$ Richard Coyne, Technoromanticism: Digital Narrative, Holism, and the Romance of the Real, p.4. See also Slavoj Zizék, «Is it Possible to Traverse the Fantasy in Cyberspace?», in The Zizék Reader, London: Blackwell, 1999.

43Pierre Lévy, Collective Intelligence: Mankind's Emerging World in Cyberspace, p.xxv. See Richard Skeates, «The Infinite City» in City 8, pp.6-20; Matthew Gandy, «Cyborg Urbanization: Complexity and Monstrosity in the Contemporary City», International Journal of Urban and Regional Research, vol. 29, nº1, March 2005, pp.25-49.

${ }^{44}$ Peter Stalybrass and Allan White, The Politics and Poetics of Transgression, New York: Cornell University Press, 1986, p.3.

${ }^{45}$ Oxford English Dictionary, vol. VI, Oxford: Oxford University Press, 387 
metonym of the pathological present, the fragmented status of which contrasts with the «intelligent city», which «should be understood as a moral and political entity rather than a physical place». ${ }^{46}$ On this reading, digital technologies are both invasive and remedial, creating «urban space» and cyberspace. Yet to accept this reading involves a tacit acceptance of its underlying vision of a two worlds' ontology, structured around a space (and time) of plenitude - the city, with its inferred holistic integrity and ontological purity - and an «urban world» whose meaning is exclusively negative. Problematically, all three readings assume, to different extents, that the city-urban transaction equates to competing typologies of integrity and dissolution, between which all representation succumbs to a Manichean logic of form and formlessness. The principal difference between each is that Lévy uses a more explicit diction to clarify this ideology of the urban, particularly with its use of biomedical metaphors. In medical terms, metastasis registers «the process by which malignant disease spreads to distant parts of the body, and also to the secondary tumours resulting from this process». ${ }^{47}$ Figured as a type of cancer, Lévy's «urban» represents an invasive presence, an outgrowth, from an originary design. The initial appearance of dissolution of relational difference is wrong, since by negatively engendering the logics of dissolution, Lévy affirms the legitimacy of the (by now receding) city-countryside dualism. With suitably terminal overtones, this cancer of recalcitrant urbanisation infers the unruly and malignant growth of «urban life», whose development offsets the waning identity of

«Our mammoth cities [that] are no longer cities. World-cities, inflationary megalopolises, black holes strung across the planet, monstrous attractors: Lagos, Calcutta, Cairo, Mexico City, Los Angeles, the unliveable city, city of automobiles, Tokyo, city of chaos.» ${ }^{48}$

Having outgrown their chimerical level, these «monstrous attractors» attain a nebulous definition whose indolence speaks more of a facile ideal than it does of any specific city. By appropriating biological models of development to represent spatial morphology, the typology of «inflationary megalopolises» and its analogues are erroneous because they are predicated upon an unsubstantiated and unqualified paradigm of optimum growth. Concomitantly, Lévy's urban is an arbitrary concept: deployed at will: afforded the licence of self-justification, it disregards the conventions of conceptual definition. For example, cancer is a «general term used to refer to a malignant tumour, irrespective of the tissue of

46Pierre Lévy, Collective Intelligence: Mankind's Emerging World in Cyberspace, p.70.

${ }^{47}$ Gordon Mcpherson, ed., Black's Medical Dictionary, London: A \& C Black, 2002, p.399.

48Pierre Lévy, Collective Intelligence: Mankind's Emerging World in Cyberspace, p.178. 
origin». Its theory of development is mechanistic, based upon a principle of deviation from an original cellular structure that results from the failure of regulatory mechanisms. ${ }^{49}$ Analogously, the dispersal of the 'territorial distinction' registers in symptoms of (spatial) pathology. However, Lévy elides the complex biological issues of cellular development within cancer, and so charges 'circulation' with the failure of regulatory mechanisms that result in the «detritus» of «Calcutta» and other such waste elements. In the name of «detritus», so whole swathes of places, replete with individual histories and circumstances, are circumscribed under the crass generalization of the urban. Lévy's global city is an oxymoron synonymous with an occluded topology of power, a term (and terrain) that, in common with Mitchell, glosses over the material dynamics of inequality to present a specious critical framework mounted around the receding identity of the city.

And so the broader significance of the biomedical trope becomes evident. That detritus refers to the «wearing away or down by detrition, disintegration, decomposition» and the «matter produced by the detrition ... a mass or formation of this nature», indicates its contradictory signification, both as symptomatic (of the erosion process) and illustrative (of the by-product thereof). ${ }^{50}$ This is the principal conceptual flaw in such readings of the urban, a derisive prefix whose lack of specificity is deemed symptomatic of its pathology, when in fact it signals its uniform lacunae. The city, no more the a priori paragon of authentic definition, is by now the a posteriori index of a retrograde present. This constitutes an immanent tension in the city-urban transaction. The idealized city does not refer to a material form, whilst its present «crisis» has meaning only insofar as the urban is the obverse of an idealized form. Caught within a hermeneutic circle, there is no «room», epistemologically and ontologically, for any interstitial point of reference. As such, the urban corresponds to the third definition of detritus, as the «waste or disintegrated material of any kind; debris». ${ }^{51}$ Indiscriminately connoting the residual by-product of «circulation» or the «spaces of flows», the «urban world» engenders «world-cities», spatial planes that have somehow outgrown their optimal limits («inflationary megalopolises», «mammoth cities») and so threaten to assimilate all external reference points («black holes»).

To recount, the use of the cancer metaphor articulates the anxiety that the city is redundant, or at the very least endangered, because its present state has somehow

${ }^{49}$ «It is now widely accepted that cancer results from acquired changes in he genetic make-up of a particular cell or group of cells which ultimately lead to a failure of the normal mechanisms regulating their growth», Gordon Mcpherson, ed., Black's Medical Dictionary, p.94.

${ }^{50}$ Oxford English Dictionary, vol. IV, p.557

${ }^{51}$ Oxford English Dictionary, vol. IV, p.557 
surpassed an inferred yet unqualified state of nature. Consequently its identity is only conceivable in the negative, amorphous terms attributed to the urban. That said, its metaphorical use is undercut by a fundamental misconception. Typified by «mammoth cities» of «chaos», Lévy's urban cancer - an elaboration of the cityurban transaction - signifies an ineluctable process whose prognosis requires remedial intervention. To counteract a contaminated material realm the tenuous concept of the virtual world is forwarded. ${ }^{52}$ Allied to this is a wilful ignorance to the fact that, although traditionally imbued with negative meaning, «It is entirely wrong to see cancer as a single disease entity with a universally poor prognosis». It is a far from uniform condition, with mutable growth patterns and asymmetric morphology ${ }^{53}$ In other words, the concept of cancer is very different to its material form. It is not a type of detritus, nor can its form be accorded a generalized pathology, for its becoming is not subject to laws of linear or teleological development. Like the widespread use of the urban as an undifferentiated term that elusively refers to simultaneously localized and globalized processes of homogenization, Lévy's stilted understanding of oncological concepts is symptomatic of contemporary representations of the city and the urban alike.

Warehouses, industrial zones, the forgotten housing development lost between a beet field and an airport, suburbs, new towns, commercial centres, all those places that are no place, unconsecrated, without history, agglomerated by new circuits, will never constitute a city. They are peopled, but we are incapable of inhabiting them ${ }^{54}$

Read as a series of analogues for a listless present, these «agglomerated» places are couched in a rubric of periphery (another timeless and mythical concept), against which the city - replete with history - assumes the rank of centre. This use of place, which assumes the past was significant because it contained «real» cities, provides the basis for critical distance, against which the present is «without history» (and so «will never constitute a city»). Yet this city-urban transaction is far from innocuous, for it masks the fact that urbanism, as the institutionalized application - and representation - of a particular rationality, «implies the intervention of power more than understanding». ${ }^{55}$ Understanding, in terms of qualified definition, is

${ }^{52}$ As Zizék notes, «the a priori possibility of viruses disintegrating the virtual universe point towards the fact that, in the virtual universe as well, there is no 'Other of the Other', that this universe is a priori inconsistent, with no final guarantee of its coherent functioning»; Slavoj Zizék, «Is it Possible to Traverse the Fantasy in Cyberspace?», p114.

${ }^{53}$ Gordon Mcpherson, ed., Black's Medical Dictionary, p.94. The morphology of cancer cells reveals that «they may show a lesser degree of differentiation (i.e. they are more 'primitive'), features indicative of a faster proliferative rate and disorganized alignment in relationship to other cells or blood vessels». ${ }^{54}$ Pierre Lévy, Collective Intelligence: Mankind's Emerging World in Cyberspace, p.178.

${ }^{55}$ Henri Lefebvre, The Urban Revolution, p.160. 
transposed by the application of brutal homogenization. Negotiated through the domain of geographical space, inequalities of the social order are naturalized through the generic typology of «all those places that are no place», «peopled» by a subspecies repudiated at the level of sovereign identity, for «we are incapable of inhabiting them». Collaterally, the switch from the plural («places») to the singular («place») signals essentialist and dehistoricized understandings of place and city alike, whose lack of contingent basis mirrors the timelessness of centre-periphery epistemologies. The «forgotten housing developments» are condemned to a nonhistorical identity because of their lack of acquiescence with regard to traditional paradigms of city, suburb, or countryside. And so history, in this sanctioned and sanitised form, traduces - in the name of the urban - that which does not accord with its legitimate definitions. As an instance of the logics of dissolution, this urban «detritus» is literally no-where, spatially and temporally, for it languishes in the torpor of conflated idealism and empiricism, conceptually flaccid and materially redundant. It is precisely from within these abject realms of (non-) history that John King's urban form emerges.

\section{A Different View}

To date, John King is the author of six texts. ${ }^{56}$ Perhaps best known for the recently filmed first novel, The Football Factory [2004, dir. Nick Love], King's oeuvre can be provisionally distinguished thematically, though this is not to suggest a discontinuity. The first two novels, The Football Factory and Headhunters, are set in late twentieth-century working class England, whilst England Away incorporates more diverse geographical settings. Adopting an Irving Welsh-esque brutality of colloquial expression, the trilogy engages themes of identity within the context of football hooliganism. Home to a series of «undesirable» characters, frequently «white, Anglo-Saxon, heterosexual and fed up of being told [they were] shit», their recurrent subject matters - disconcerting perspectives on white working class ethnicity, masculinity, alienation, racism and homophobia, violence and drugs refuse the platitudes of marginality. ${ }^{57}$ Set respectively in Slough and the "urban sprawl of the provinces», Human Punk and White Trash extend earlier geographical, historical, and thematic preoccupations to engage an increasingly prevalent

${ }^{56}$ John King, The Football Factory, London: Jonathan Cape, 1996. This edition published London: Vintage, 2004; Headhunters, London: Jonathan Cape, 1997. This edition Vintage, 1998; England Away, London: Jonathan Cape, 1998. This edition London: Vintage, 1999; Human Punk, London: Jonathan Cape, 2000. This edition London: Vintage, 2001; White Trash, London: Jonathan Cape, 2001. This edition London: Vintage 2002; The Prison House, London: Jonathan Cape, 2004. For the purposes of this paper, The Prison House is not referred to

${ }^{57}$ John King, The Football Factory, pp.116-117. 
political disaffection. ${ }^{58}$ Continuing King's concerns with the influence of the media and the effects of post-industrialization on conceptualizations of gender and the city, these texts, far from being «without history», produce a series of counterintuitive perspectives that refuse to be incorporated within orthodox discourses and assumptions. They include perspectives that, for the purposes of this paper, delineate the logics of dissolution affecting the forms of urban representation.

«... the spread of houses and factories the same as a plastic model ... power grids, industrial ley lines melting down as the sun scorches the earth and the reservoirs boil and sink, slow columns of steel and rubber oozing past concrete blocks, slate terraces fanning out from the train track, car parks and gas tanks ... a wood to the east, patches of yellow where the fields have died ... chemical visions and exhaust hallucinations ... concrete cows in a concrete paradise, the black-tarmac snake of the motorway passing through dreamland.» ${ }^{59}$

Viewed through thermal imaging cameras, this «dreamland» registers the ubiquitous presence of, and mediation afforded by, various forms of technologies. ${ }^{60}$ Framed by technology, it constitutes an urban form extensively re-envisioning nature as part of the shift towards a «fully urbanised ontology» that affects the morphology and content of the urban: its quantitative and qualitative aspects. ${ }^{61}$ Where post-Cartesian ideologies of nature as dormant matter were symptomatic of the foundational split of modern epistemologies, providing the «cultural sanctions» necessary for its denudation, this «concrete paradise» contends the veracity of the bounded city. ${ }^{62}$ Displacing the idea of passive nature for the always-already constructed-ness of «chemical visions», the synthetic overtones of the «plastic model» play off the idea of an organic plan. Traditionally associated with

\footnotetext{
${ }^{58}$ John King, White Trash, p.9.

${ }^{59}$ John King, p.4.

60Jay David Bolter and Richard Grusin, Remediation: Understanding New Media, London: MIT Press, 1999. ${ }^{61}$ Richard Skeates 'The Infinite City'. On the emergence of mechanization and associated ideologies of nature and society, see Carolyn Merchant, The Death of Nature: Women, Ecology and the Scientific Revolution, San Francisco: Harper \& Row, 1980; Brian Easlea, Fathering the Unthinkable: Masculinity, Scientists and the Nuclear Arms Race, London: Pluto Press, 1983. See also Robert Romanyshyn, Technology as Symptom and Dream, London: Routledge, 1989; Stephen Toulmin, Cosmopolis: the hidden agenda of modernity, Chicago: University of Chicago Press, 1992.

${ }^{62}$ Carolyn Merchant, The Death of Nature: Women, Ecology and the Scientific Revolution, p.2. In the words of Easlea : «Truth would be the means to technological power over nature ... It would be a truth that would consist of nature's hidden «forms» ... conceptually transforming «her» [nature] into a lifeless, machinelike entity of mere matter in motion», Brian Easlea, Fathering the Unthinkable: Masculinity, Scientists and the Nuclear Arms Race, p.22. A transformation that, as Lefebvre notes, speciously distinguishes between «nature (physis) and logos (reason)», Henri Lefebvre, The Urban Revolution, p.25.
} 
nineteenth-century industrial cities, the organicist conceptualization relies on the functional analogy of urban spatial dispersal with the arrangement of human organs. ${ }^{63}$ Typified by the use of biological metaphors to connote a belief in holistic integrity, this anatomical conception of space deigns cities "healthy" or otherwise according to their similitude with a dehistoricized plan. Yet for King this use of an ideal form is neither desirable nor possible. If the "spread of houses and factories» are «the same as a plastic model», this similitude raises the issue of critical distance. Their likeness does not refer to the proximity of ideal and re/presentation. Instead it recognizes a logic of dissolution, in the first instance regarding the ontological distinction between culture and nature. Forthwith indivisible, the oxymoronic «concrete cows» recognize nature as a «second-order schema» providing insufficient basis for critical distance. ${ }^{64}$ Subject to recursive appropriation, the «black tarmac snake» of the motorway collapses relational difference: it leaves a thoroughly culturalized-nature whereby the «tropical paradise off the hard shoulder» undercuts dystopian associations of «concrete paradise» by means of oxymoronic juxtaposition. ${ }^{65}$ Paradise and concrete, two terms not normally associated, become as one in the logic of the urban. Without traducing this «concrete paradise» via the narration of the uncanny, the lack of relational difference creates an environment immeasurable and indefinable by the orthodox referents of «nature», «countryside», or «suburb». The "patches of yellow where the fields have died» signals the dissolution of critical practice couched in an outmoded rubric of autonomous «nature». The «slow columns of steel and rubber oozing past concrete blocks» suggests that nostalgia for an immutable nature - like that of the city - is outmoded. ${ }^{66}$ Accordingly, the «melting down» of «industrial ley-lines' plays on the latter defined as the «joining [of] two prominent points in the landscape, thought to be the line of a prehistoric track». ${ }^{67}$ The conjoining of prehistoric and industrial elements, by refuting a neat discrimination between chronological periods with discrete physical characteristics, serves notice that the trope Raymond Williams takes for granted in recollecting «what seems like an unmediated nature», is no longer - if it ever was - valid. ${ }^{68}$ Traversed by «power grids», mediated by thermal imaging cameras, and bisected by «train track», the pastoral ideal is negated.

${ }^{63}$ See Matthew Gandy, «Cyborg Urbanization: Complexity and Monstrosity in the Contemporary City», pp25-49.

${ }^{64}$ Roland Barthes, Mythologies, trans. Annette Lavers, Hertfordshire: Paladin, 1973, p.131

${ }^{65}$ John King, White Trash, p.4.

${ }^{66}$ «The pastoral mode, although it viewed nature as benevolent.» Merchant notes, 'was a model created

as an antidote to the pressures of urbanization and mechanization', Carolyn Merchant, The Death of

Nature: Women, Ecology and the Scientific Revolution, p.9. See also Raymond Williams, The Country and the

City, London: Hogarth Press 1993, pp.13-34.

${ }^{67}$ Collins Concise English Dictionary, p.647.

${ }^{68}$ Raymond Williams, The Country and the City, p.3. 
Nature is hereon approached by degrees of approximation: an orchard, whilst «not proper countryside», is «good enough». ${ }^{69} \mathrm{In}$ sum, «nature» constitutes an ersatz, polluted backdrop: mired in the violence of inscription and historical appropriation, the decaying vestiges of authenticity, in the guise of «dying fields», are supplanted by the synthetic residuum of industrialization. As an all-encompassing urban form, the traditional points of distinction, between centre and periphery, culture and nature, no longer inhere. Rebuking notions of geographical distinction, this «concrete paradise» drifts «out to the satellite towns burning bright on the horizon».70 This leads to the second logic of dissolution. Where steel and rubber tessellates with concrete to supplant the organicity of an «unmediated» nature, so the urban metaphors of this «oozing» entity, fanning out, are without rational telos - it is not hemmed in by countryside or suburbs. As an urban form, it is non-linear, complex, subject to deviation: city and nature assume the rank of an all-inclusive rubric.

«Cities have split into the countryside ... Britain is a post-industrial society, but the image...is stuck in grainy black-and-white footage ... Heavy industry has been and gone, the green fields of England soaked in insecticide. Protesters travel by coach and the pits have been flooded. The East End has moved out to Essex and the peasants are all tuning into digital TV.»11

Contra the emphases upon totality and autonomy characterizing the city-urban transaction, the «long old urban sprawl of the provinces» connotes an urban morphology renouncing the structure of rational organization. ${ }^{72}$ It is a totally internalized discourse, a figurative and symbolic 'split' realigning critical distance. Formed by the (at times forcible) dispersion of the transit-oriented city, this environment consists of the diffusion of communications technologies that indicate different relations with nature and new patterns of mobility. Negotiated by communications networks, the spaces opened by modern technologies are traversed nationally by motorways and, transnationally, via mobile communications and air travel: «The sky's jammed with jets queuing to land at Heathrow, suntanned passengers looking down on the glass, bricks, streets of our town». ${ }^{73}$ Symbolized by «glass» and «brick», the existential horizon of the «satellite towns» becomes the dominant form of experience, unencumbered by the traditional

Carolyn Merchant, The Death of Nature: Women, Ecology and the Scientific Revolution, p.9; John King, Human Punk, p.41.

70John King, Headhunters, p.292.

${ }^{71}$ John King, Human Punk, p.258 and p.259.

72John King, White Trash, p.9.

${ }^{73} \mathrm{John}$ King, Human Punk, p.340. The metonymic view of the city from the train is a recurrent textual motif: see The Football Factory, p.225; England Away, p.129; Human Punk, p.85, p.216, and p.316. 
limits of the city. ${ }^{74}$ Far from being «forgotten», and anything but «nameless», these dispersed elements register a new urban paradigm, reflexively aware of its contingent and arbitrary status as «satellite towns», since the «centre» around which it orbits - London - is perpetually decentred. ${ }^{75}$ Contrary to associations with centrality and power, London becomes displaced: where the East End spills out into Essex, into «new model estates», so the euphemisms of «urban malaise» are signally absent. ${ }^{76}$ Typically represented as «squalor» and «uncontrolled sprawl», that which lies beyond the mythic plenitude of the centre is often euphemistically inscribed as the «chaotic growth» of «ever-extending suburban sprawl», with its collateral «deadening impact on our landscape». ${ }^{77}$

Such vitiated rhetoric is uniformly absent within the «great arterial roads to the London country sprawl surrounding the capital» that denote a «low-lying landscape» of «satellite towns» and «new-brick estates connecting villages and junctions, lining the trunk roads».78 Part of «the boom towns and sprawl of Outer London and the Thames Valley», it is not suburbia in any conventional sense, for in no way is this a peripheral postscript to London. ${ }^{79}$ This «paradise» emerges out of the dispersed East End: released from its typically delimited (assumedly selfevident) location, it drifts without ultimate (teleological or dystopian) ascription. The «great arterial roads» indicate the reciprocity between the «country sprawl» and the "capital», nourishing «the trade routes dipping into the new towns, oneman labs and small businesses flourishing in the back streets of an England the cameras never record». ${ }^{80}$ An England unrecorded because the «cameras» fail to capture the contingent status of centre and periphery, culture and nature alike. This leads to the third logic of dissolution. No longer dissociated from countryside, cities «split», and so the displacement of the East End into Essex prompts a quantitative shift in the morphology of the city and changes in the structure of representation. That Britain is a "post-industrial society» is, on this reading, to contend the lassitude of heritage. The "grainy black-and-white footage» speaks of another moment, steeped in an obsolete iconography of the «rolling fields of England's

\footnotetext{
${ }^{74}$ John King, Headhunters, p.234

75Pierre Lévy, Collective Intelligence: Mankind's Emerging World in Cyberspace, p.178 («forgotten housing development»); Manuel Castells, «Space of Flows, Space of Places: Materials for a Theory of Urbanism in the Information Age», p.86 («nameless urban constellations»).

${ }^{76}$ John King, White Trash, p.9; Rogers 2000: 43: 'As social cohesion and informal controls weakens, so our ability to contain disorder and violence declines'

${ }^{77 R i c h a r d ~ R o g e r s}$ and Anne Power, Cities For A Small Country, p.27 and p.72.

${ }^{78}$ John King, Human Punk, p.233.

${ }^{79}$ John King, p.230.

${ }^{80}$ John King, p.248.
} 
green and pleasant land».81 This environment is, in contrast with (and leagues away from) the imperial majesty of «green and pleasant land», saturated in «insecticide». The dissolution of past forms of representation does not, of itself, herald a «truer» picture, but one recognizing the complicity, the specious character, of such contentions. What remains is the attempt to locate urban representation beyond the polarities of the global city, within the contingent and arbitrary interstices of myth and history otherwise known as the M25.

«One day this motorway will be lined with concrete, the Thames Valley a solid block of housing estates fed by service-station mini-markets and warehouse superstores, a spread of car parks and shopping malls, multiplex cinemas and fast-food strips. In the old days there were city walls around the ruler's towers, and now there's the M25. We're working to an American model, extending the highways and cutting down on public transport, spreading out, more and more people flushed out of London by the rich.» ${ }^{82}$

The frequent caesurae of motorways, railways, and airports spanning these synthetic backdrops acknowledge that the city - if it is to retain workable definition - must reconcile new relations with nature and mobility that do not fit within older structures of feeling. This image of the Thames Valley recognizes firstly, that the city can no longer be - if, indeed, it ever was - conceived as an elementary form, hygienically bounded by countryside. This «solid block» of housing and trading estates, «lined with concrete», is conventionally immeasurable. Relinquishing positivist assumptions of scale, it does not fit traditional hermeneutics concepts. No longer navigable by the «endless quest» of the detective or flâneur decoding its chaos, this «American model» is extended in perpetuity, a «spread» fundamentally experienced through - and re-presented in terms of the volition of the automotive or aircraft journey. ${ }^{83}$ Its scale is indicated by the dissembled perimeter of London, symbolized by the M25, «spreading out» and «fed» by a plethora of consumerist facilities. This leads to the second, and most important, recognition, that London - the city more generally - has, and continues to, reside in myth. «In the old days» - a mythical past, home to authentic forms - the significance of the bounded city was primarily as a physical and semiotic prophylactic «around the rulers towers»; presently «there's the M25». This present day frontier - a «conceptual ha-ha» - decries the myth of the autonomous and rational city. ${ }^{84}$ The limits of London, once believed to be physically

81John King, The Football Factory, p.123.

${ }^{82}$ John King, Human Punk, p.257.

${ }^{83}$ Anthony Vidler, (): The Architectural Uncanny: Essays in the Modern Unhomely, Cambridge, MA: MIT

Press, 1992, p.4.

${ }^{84}$ Iain Sinclair, London Orbital, London: Penguin 2003, p.3. 
demonstrable, have waned. Now, «[t]here's probably more white Londoners outside the M25 than there is in London proper, from Margate to Milton Keynes, Southend to Reading». ${ }^{85}$ The disingenuous idea of a «London proper» is undermined by its volatility: uncoupled from its traditional moorings of centrality, London drifts interminably. Akin to the displaced East End, and given the instability of that which lies within the M25 - let alone its outer limits - the relations between centre and periphery, urban and suburban, city and countryside, become historically contingent, suggesting these terms to be myths that have - and continue to - perpetuate hegemonic socio-economic structures. Myths of origins, of inclusion and exclusion, rooted in the differential applications of «power»: the extension of highways and diminution of public transport, involving the forcible flushing out «of London by the rich», locates the suppositious «centre» within the actions of a privileged minority. Yet its status is far from assured: its links to the «ruler's towers» denaturalizes the critical, historically and geographically contingent bases of such typologies. Typologies for which this image of the Thames Valley as a «solid block of housing estates» does not fit, neither city, suburb, nor country. It is an irrational, anomalous form, a complex but nevertheless not intangible nor unrepresentable form, for which previous metropolitan and provincial tropes insufficiently discern.

\section{Conclusion}

To conclude, this is not the global city as it is conventionally figured. Nor, for that matter, is it the urban obverse that typically follows such accounts. It is an ontological terrain that, epistemologically aware of its inherent contingency, can only be partially and transitorily represented. In order to surmount the strictures of relational difference and be represented in a more attenuated manner, the complexities of these urban present/s require logics of dissolution not merely in a negative sense. It is not enough to contend the irrelevance of a «territorial distinction» that "gives way to urban life», if the latter consists of the «detritus» of «all those places that are no place». ${ }^{86}$ Equally, the imputed universality of the «Hertzian landscape», for all that it creates a land of fulsomeness and plenitude, is at the same time one of ideal vacuity, a depopulated landscape whose symbolic and ideological system elides the materiality of inequality in the name of an ineluctable "curve of technological development». ${ }^{87}$ Where the former creates reductive typologies of form and formlessness, the latter eliminates even this crude basis for

85John King, The Football Factory, p.257.

${ }^{86}$ Pierre Lévy, Collective Intelligence: Mankind's Emerging World in Cyberspace, pp.177-178

${ }^{87}$ William J. Mitchell, Me++: The Cyborg Self and the Networked City, p.5 and p.55. 
spatial distinction in its careless reification of «technology». Moreover, diagnoses of the «great urban paradox» do not advance matters, for they re-polarise culture and nature: the quantitative discrimination between city and countryside is transposed by the qualitative distinction between city and urban. ${ }^{88}$ The dissolution of an outmoded epistemological practice should not be read as heralding a parallel sense of ontological collapse that leads to the homogenization of spatial (and in turn cultural, political, and social) differences, for «no urban place is identical to another» .89 The insufficiency of traditional co-ordinates does not mean the present is, or should be, represented pathologically. Far from it. A pensive logics of dissolution, aware of the epistemological problems of representation, of the transience of identity, of the partiality of experience, and of the continuity of change, shuns the obstinacy of the normative; it deals with tendencies and orientations. In the words of King: «The best thing about life is that there's always something new coming through», a new ontology whose mantra reads «wherever there's people life blooms». ${ }^{90}$

${ }^{88}$ Manuel Castells, «Space of Flows, Space of Places: Materials for a Theory of Urbanism in the Information Age», p.89.

${ }^{89}$ «In spite of any efforts at homogenization through technology, in spite of ... separation and segregation, no urban place is identical to another», Henri Lefebvre, The Urban Revolution, p.40.

${ }^{90}$ John King, Human Punk, p.258 and p.316. 